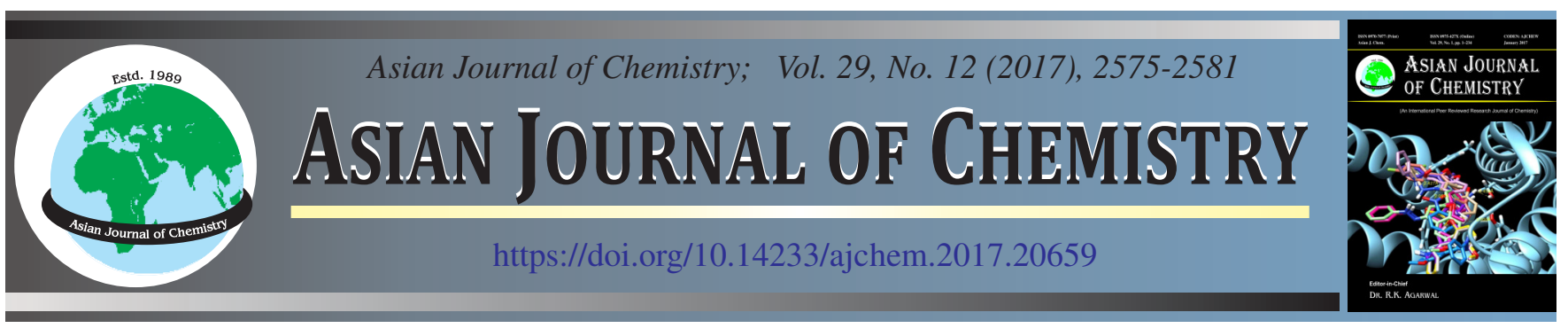

\title{
Study of Particle Incorporation and Performance Characteristic of Aluminium Silicate-Zirconia Embedded on Zinc Rich Coatings for Corrosion and Wear Performance
}

\author{
O.S.I. FAyOmi ${ }^{1,2, *}$, A.P.I. Popoola ${ }^{1}$, O.O. IGE $^{3}$ and A.A. Ayoola ${ }^{4}$
}

${ }^{1}$ Department of Chemical, Metallurgical and Materials Engineering, Tshwane University of Technology, P.M.B. X680, Pretoria, South Africa ${ }^{2}$ Department of Mechanical Engineering, Covenant University, P.M.B 1023, Ota, Ogun State, Nigeria

${ }^{3}$ Department of Materials Science and Engineering, Obafemi Awolowo University, Ile-Ife, P.O BOX 220282, Osun State, Nigeria

${ }^{4}$ Department of Chemical Engineering, Covenant University, P.M.B 1023, Ota, Ogun State, Nigeria

*Corresponding author: E-mail: ojosundayfayomi3@gmail.com; ojo.fayomi@covenantuniversity.edu.ng

Composite coatings of $\mathrm{Zn}-\mathrm{Al}_{6} \mathrm{O}_{13} \mathrm{Si}_{2}$ and $\mathrm{Zn}-\mathrm{Al}_{6} \mathrm{O}_{13} \mathrm{Si}_{2}-\mathrm{ZrO}_{2}$ were electroplated on mild steel from $\mathrm{Zn}^{2+}$ ions bath and homogeneously dispersed nano $\mathrm{Al}_{6} \mathrm{O}_{13} \mathrm{Si}_{2}-\mathrm{ZrO}_{2}$ particulates were achieved. The corrosion resistance characteristics of the deposited coatings were evaluated by linear polarization method. The microstructural properties of the multilayer produce coatings were examined by scanning electron microscope equipped with energy dispersive spectrometer, X-ray diffraction and atomic force microscope. The thermal deformation were observed in $250^{\circ} \mathrm{C}$ for $4 \mathrm{~h}$ and mechanical properties of the composite coatings were investigated using diamond base Dura scan microhardness tester. From the observed results, it was shown that the incorporation of particles into the electrolyte change the microstructure characteristics of developed composite and improved drastically the thermomechanical performance of the coatings.

Keywords: Thermal stability, Microstructure, Corrosion, Composite coatings.

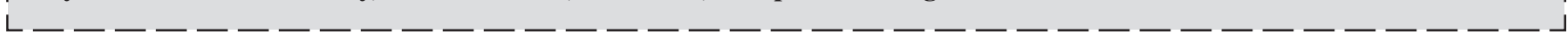

\section{INTRODUCTION}

Massive applications of mild steel as materials of construction in various industries are well documented. Mild steel exhibits low cost, readily available and good mechanical characteristics among others [1-4]. The most prominent concern is the huge degradation rates associated with this material. Generally, several approaches exist in reducing the material wastages most especially in tribocorrosion environment and these include: inhibition, materials selection, electrochemical (anodic and cathodic) protection and coating. Literature survey shows that coating is becoming popular to minimize the wastages rate associated with mild steel due to its benefits compared with others [5-12].

Primarily composite coating is adjudged to confer adequate protection and basically, $\mathrm{Zn}$ electrodeposition is widely applied due to its excellent corrosion and mechanical behaviour. In spite of this, they are subjected to short life span and high deterioration rate in aggressive environment. It was on this basis that concerted efforts are adopted by various studies to improve on these limitations. The consensus was that surface modifications greatly assist the strengthening mechanisms and minimize occurrence of material wastages. The functionality of good composite coating is greatly affected by the microstru- ctural characteristics and as such there abounds, many literature detailing the effects of microstructure, grain growth and texture of the coating constituents on the performance [12-14]. For example, the presences of different phases are responsible for better performance of composite coating response to external loadings. A study evaluated the interfacial reaction, microstructural and functional properties of $\mathrm{Zn}-\mathrm{Al}-\mathrm{SnO}_{2} / \mathrm{TiO}_{2}$ and it was shown that mechanical and corrosion behaviour were dependent on the microstructure [12]. It was on this basis that thorough examination of crystal morphology, structure of multifaceted hybrid $\mathrm{Zn}$ based coatings fabricated together with the electrochemical properties are being considered in this study.

Recently, there is an upsurge in application of $\mathrm{Zn}$ based coatings and several works have been done on $\mathrm{Zn}$-metallic and $\mathrm{Zn}$-non-metallic composites coating $[15,16]$. These were due to favourable coating thickness, easy of fabrication and relatively low cost. The comparative advantage offer by composite coating over ordinary $\mathrm{Zn}$ coating makes them attractive. Binary Zn based composite coating exhibits superior surface properties [16-18]. Kumar and Venkatesha [19] studied the fabrication and electrochemical corrosion behaviour of $\mathrm{Zn}-$ $\mathrm{TiO}_{2}$ composite and concluded that the incorporated $\mathrm{TiO}_{2}$ nanoparticles enhanced the compactness, microstructure and topography compared to pure $\mathrm{Zn}$ coating. In essence, the incor- 
TABLE-1

CHEMICAL COMPOSITION OF MILD STEEL

\begin{tabular}{ccccccccc}
\hline Elements & $\mathrm{C}$ & $\mathrm{Mn}$ & $\mathrm{Si}$ & $\mathrm{P}$ & $\mathrm{S}$ & $\mathrm{Al}$ & $\mathrm{Ni}$ & $\mathrm{Fe}$ \\
\hline$\%$ & 0.15 & 0.45 & 0.18 & 0.01 & 0.031 & 0.005 & 0.008 & 99.16 \\
\hline
\end{tabular}

poration of more phases lend to confer adequate service requirement on the coating alloy. On this basis, the new trend in composite coating is to produce and characterize quartenary metal-ceramic composite $[13,20,21]$.

Interestingly, efforts have proved that ceramics composites $\left(\mathrm{Al}_{2} \mathrm{O}_{3}, \mathrm{SiO}_{2}, \mathrm{SnO}_{2}, \mathrm{TiO}_{2}, \mathrm{ZrO}_{2}\right)$ have novel properties that are favourable towards hardness, wear and corrosion resistance. Currently despite vigorous literature review, there was little information on quaternary composite coating fabricated using electrolytic route. Recent research on the mechanical response of zirconia reinforced composite coating produced by electrolytic co-deposition technique on mild steel concluded that the zirconia has positive effect on the produced composite with improved hardness and anti-wear resistance properties [21]. The present study is a further attempt to evaluate the electrochemical and thermal stability of the $\mathrm{ZrO}_{2}$ particle loading on $\mathrm{Zn}-\mathrm{Al}_{6} \mathrm{O}_{13} \mathrm{Si}_{2}$ in chloride solution on mild steel. Additional information generated was microstructural characterization of the morphological crystal structure and topography with the aid of atomic force microscope (AFM), scanning electron microscope equipped with energy dispersive spectrometer (SEM/EDS) and optical microscope (OM), while the phases present were determined using X-ray diffractometer (XRD).

\section{EXPERIMENTAL}

Preparation of substrate: Mild steel specimens of dimension $(30 \mathrm{~mm} \times 20 \mathrm{~mm} \times 1 \mathrm{~mm})$ sheet were used as substrate and zinc sheets of $(40 \mathrm{~mm} \times 30 \mathrm{~mm} \times 2 \mathrm{~mm})$ were prepared as anodes. The initial surface preparation was performed with finer grade of emery paper as described in previous studies $[3,22]$. The sample were properly cleaned with sodium carbonate, pickled and activated with $5 \% \mathrm{HCl}$ at ambient temperature for $10 \mathrm{~s}$ then followed by instant rinsing in deionized water. The mild steel samples were commercially obtained and the chemical analysis is as presented in Table-1 while zinc anode composition was about $99.99 \%$ according to earlier report [3].

Formation of deposited coating: The plating baths were prepared by using analytical grade chemicals supplied by SMM (Ptv.) Ltd., South Africa and distilled water at room temperature, prior to plating. The bath is produced according to the formulation in Table- 2 and it is concurrently stirred for a day while heated to $40{ }^{\circ} \mathrm{C}$ to easily admix and to allow for dissolution of any agglomerate in the bath solution before plating [3]. Then, the mild steel substrates were actuated by dipping into $10 \% \mathrm{HCl}$ solution for 10 seconds followed by rinsing in distilled water.

Preparation of the coatings: The prepared $\mathrm{Zn}-\mathrm{Al}_{6} \mathrm{O}_{13} \mathrm{Si}_{2}-$ $\mathrm{ZrO}_{2}$ bath composite was heated for $2 \mathrm{~h}$ and intermittently stirred to obtain clear solution before it was prepared by electrolytic deposition process over mild steel. The prepared cathode and anodes were connected to the D.C. power supply through a rectifier as presented in Fig. 1. The distance between the cathode and anode was kept constant at $50 \mathrm{~mm}$ while electrode immer-

\begin{tabular}{ll}
\multicolumn{1}{c}{ TABLE-2 } \\
& $\begin{array}{c}\text { BATH COMPOSITION OF } \mathrm{Zn}-\mathrm{Al}_{6} \mathrm{O}_{13} \mathrm{Si}_{2}-\mathrm{ZrO}_{2} \\
\text { ALLOY CO-DEPOSITION MATRIX }\end{array}$ \\
\hline Composition & Mass concentration $(\mathrm{g} / \mathrm{L})$ \\
\hline $\mathrm{ZnSO}_{4} \cdot 7 \mathrm{H}_{2} \mathrm{O}$ & 70 \\
$\mathrm{ZrO}_{2}$ & $5-15$ \\
$\mathrm{Al}_{6} \mathrm{O}_{13} \mathrm{Si}_{2}$ & 15 \\
Boric acid & 5 \\
Glycine & 5 \\
Thiourea & 5 \\
Temp. & $40{ }^{\circ} \mathrm{C}$ \\
pH & 4.5 \\
Time & $15 \mathrm{~min}$ \\
Current density & $1.0 \mathrm{~A} / \mathrm{cm}^{2}$ \\
\hline
\end{tabular}

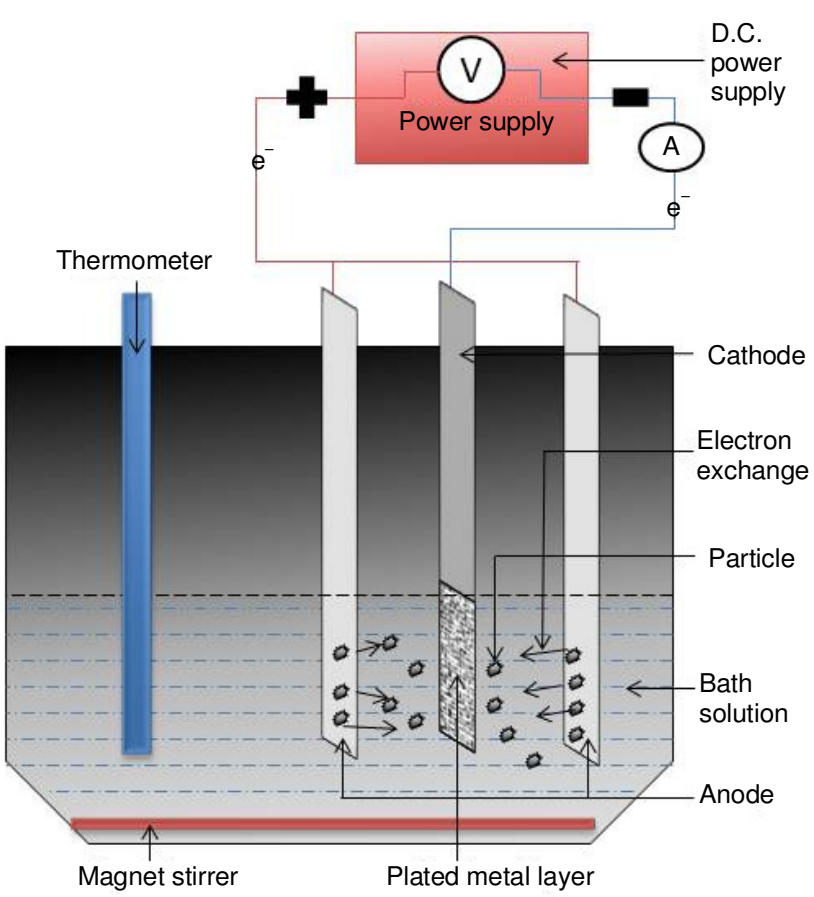

Fig. 1. Schematic diagram of electrodeposited system

sion depth were maintained at $80 \mathrm{~mm}$. Deposition was carried out at varying applied current density between $1.0 \mathrm{~A} / \mathrm{cm}^{2}$ for $15 \mathrm{~min}$. Thereafter, the samples were rinsed in water and dried. The formulated design plan for the coating is described in Table-3.

Structural characterization of coatings: The structural studies and elemental analysis of the fabricated alloy samples

\begin{tabular}{|c|c|c|c|}
\hline & $\begin{array}{r}\text { TABLF } \\
\text { FORMULATED DE } \\
\text { COMPOSITION OF Z }\end{array}$ & $\begin{array}{l}\text { NED BATH } \\
{ }_{6} \mathrm{O}_{13} \mathrm{Si}_{2}-\mathrm{ZrO}\end{array}$ & \\
\hline $\begin{array}{c}\text { Sample } \\
\text { order }\end{array}$ & Matrix sample & $\begin{array}{l}\text { Time of } \\
\text { deposition } \\
\text { (min) }\end{array}$ & $\begin{array}{l}\text { Current } \\
\text { density } \\
\left(\mathrm{A} / \mathrm{cm}^{2}\right)\end{array}$ \\
\hline A & $\mathrm{Zn}-\mathrm{Al}_{6} \mathrm{O}_{13} \mathrm{Si}_{2}$ & 15 & 1.0 \\
\hline B & $\mathrm{Zn}-15 \mathrm{Al}_{6} \mathrm{O}_{13} \mathrm{Si}_{2}-5 \mathrm{ZrO}_{2}$ & 15 & 1.0 \\
\hline $\mathrm{C}$ & $\mathrm{Zn}-15 \mathrm{Al}_{6} \mathrm{O}_{13} \mathrm{Si}_{2}-10 \mathrm{ZrO}_{2}$ & 15 & 1.0 \\
\hline $\mathrm{D}$ & $\mathrm{Zn}-15 \mathrm{Al}_{6} \mathrm{O}_{13} \mathrm{Si}_{2}-15 \mathrm{ZrO}_{2}$ & 15 & 1.0 \\
\hline
\end{tabular}


were verified using VEGA 3 TESCAN scanning electron microscope with an attached energy dispersive spectrometer (SEM/ EDS); and an Nikon optical microscope (OM). The phase property was observed with the help of X-ray diffractogram. The adhesion profile, topography and morphology of the coating were observed with the help of atomic force microscope (AFM). High optic diamond based EMCO Test Dura-scan micro-hardness tester was used to estimate the average microhardness of the deposit in an equal interval range according earlier studies.

Thermo/Electrochemical test: The mechanical stability of the coated samples was evaluated by using isothermal heat treatment (direct fired furnace atmosphere) of $\mathrm{Zn}-\mathrm{Al}_{6} \mathrm{O}_{13} \mathrm{Si}_{2}$ $\mathrm{ZrO}_{2}$ composite coating at $250^{\circ} \mathrm{C}$ for $6 \mathrm{~h}$. Thereafter, the electrochemical studies were performed with Autolab PGSTAT 101 Metrohm potentiostat using a three-electrode cell assembly in a $3.5 \% \mathrm{NaCl}$ static solution at $40{ }^{\circ} \mathrm{C}$. The working electrode was made of the developed composite coatings, platinum electrode was used as counter electrode and $\mathrm{Ag} / \mathrm{AgCl}$ was used as reference electrode. The anodic and cathodic polarization curves were recorded by a constant scan rate of $0.012 \mathrm{~V} / \mathrm{s}$, which was fixed from $\pm 1.5 \mathrm{mV}$. The corrosion rate, potential and linear polarization resistance was deduced from the Tafel corrosion analysis.

\section{RESULTS AND DISCUSSION}

SEM/EDS studies: The microstructural evaluation of $\mathrm{Zn}$ $15 \mathrm{Al}_{6} \mathrm{O}_{13} \mathrm{Si}_{2}$ composite coating is presented in Fig. 2. It was characterized with dendritic structures alongside pronounced localized degradation at the inter-diffused region. This is in line with previous reports that the disruption of the coating film can be attributed to the presence of aggressive chloride ions in the environment. Furthermore, the corrosion behaviour may be due to heterogeneity associated with the metal-medium interphase and generally the presence of grain boundaries defects leads to increase degradation attacks $[3,5,23]$. The existence of additive agents such as $\mathrm{Zn}, \mathrm{Al}, \mathrm{Si}$ and $\mathrm{Fe}$ was confirmed with the aid of EDS. It was expected that these particles will reinforced the coatings and resulted in strong blocking effect thereby preventing the intiation of stress propagation [24,25].

On the other hand, addition of zirconia $\left(\mathrm{Zn}-\mathrm{Al}_{6} \mathrm{O}_{13} \mathrm{Si}_{2} / \mathrm{ZrO}_{2}\right)$ as earlier reported [21] serve as nucleation sites and this invariably spur the zinc metal deposition (Fig. 3). This increased deposition promotes uniformly distributed and compact crystallite, excellent coating matrix, good adhesion and more nucleation sites [21,26]. Obviously, the grain boundaries defects along the interface in structure without zirconia were absent and this can be linked to appropriate dissolving particulate. Also, the superior morphology may be associated with adequate control of bath process parameters [22,26,27]. Moreover, the presence of $\mathrm{Zr}$ in admixture particulates (Zn, Al, Si and Fe) can explained the refined morphology in the EDS result and it is suspected to provide the necessary kinetics force by enhancing the bond and strengthening mechanism.

Atomic force microscopy: It must be stated that AFM results as presented in this section corroborated SEM observations. Fig. 4a shows AFM image of zirconia reinforced $\mathrm{Zn}-15 \mathrm{Al}_{6} \mathrm{O}_{13} \mathrm{Si}_{2}$ composite coating, which indicated evenly distributed and fine grain size structure, stable crystal growth with little undulation
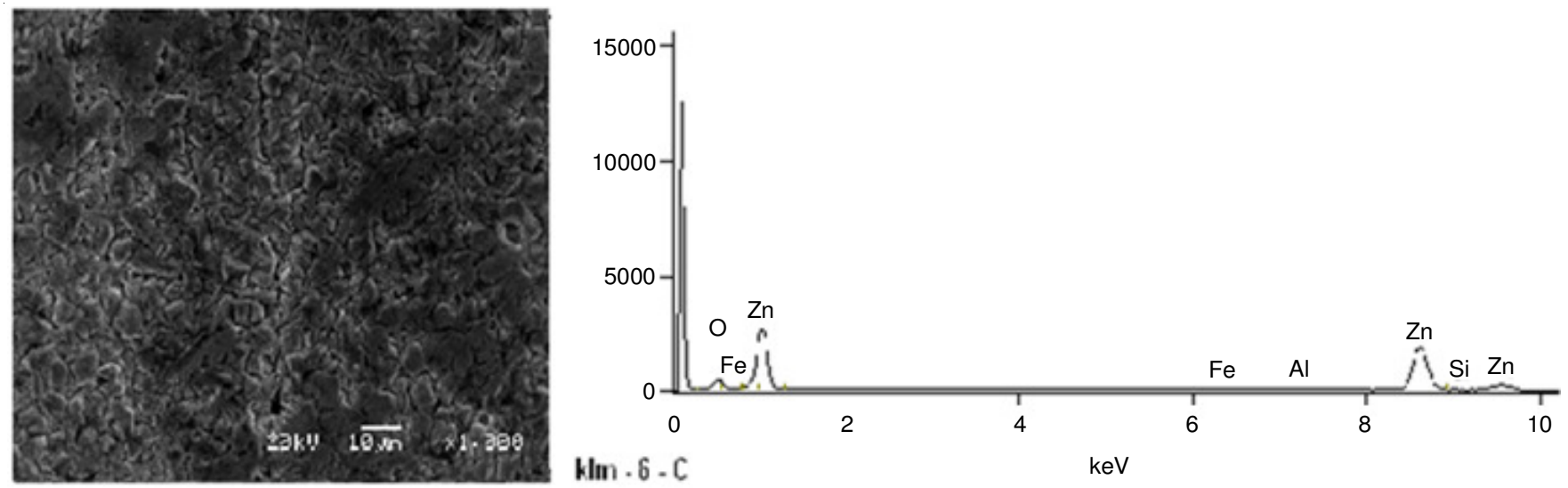

Fig. 2. SEM/EDS microstructure of $\mathrm{Zn}-15 \mathrm{Al}_{6} \mathrm{O}_{13} \mathrm{Si}_{2}$ composite coating

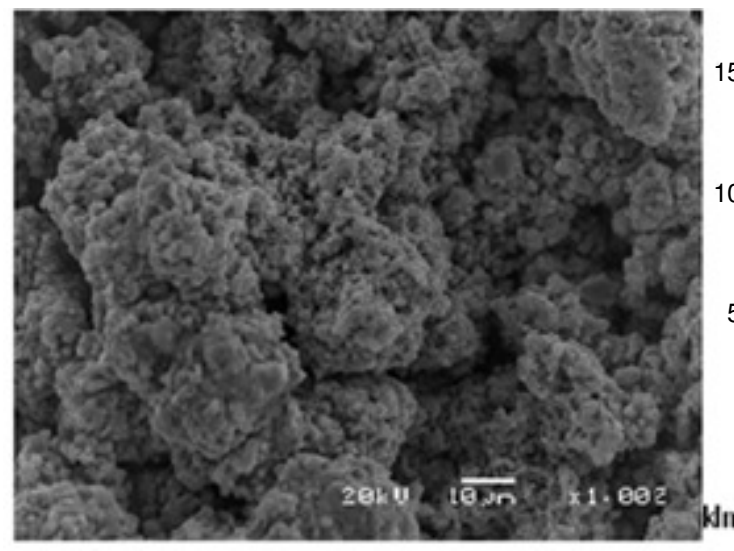

$15000-$

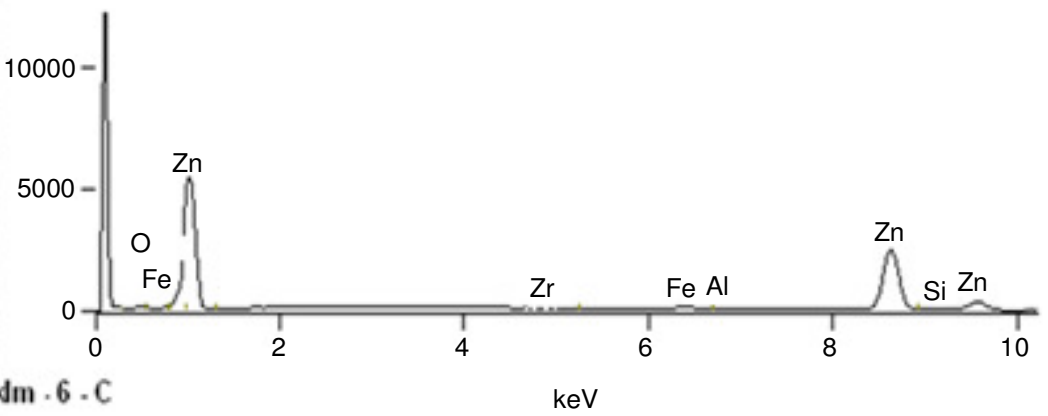

Fig. 3. SEM/EDS Microstructure of $\mathrm{Zn}-15 \mathrm{Al}_{6} \mathrm{O}_{13} \mathrm{Si}_{2}-15 \mathrm{ZrO}_{2}$ composite coating 
in the surface topography. The undulation region is regarded as the most active sites, which tends to dissolve due to insufficient bonding. This can be attributed to the fitting diffusion of the particulates into the metal nucleus and the application of satisfactory coating process parameters [28], while the incorporation of the zirconia into the matrix accounted for the undulation [1]. The surface roughness scrutiny exhibited finger-mark impression coupled with stable crystallite structures (Fig. 4b). From structural evolution point of view, the presence of fingermark will have negative impact; contrarily it will promote the coating adhesion property.

XRD studies: The XRD pattern for $\mathrm{Zn}-15 \mathrm{Al}_{6} \mathrm{O}_{13} \mathrm{Si}_{2}-15 \mathrm{ZrO}{ }_{2}$ composite coating is as presented in Fig. 5 and the major diffraction peak observed were $45^{\circ}, 52^{\circ}, 100^{\circ}$ and $108-112^{\circ}$. It is notably that there are three intermetallic phases $\left(\mathrm{ZnAl}_{3}\right.$, $\mathrm{ZnAl}_{3} \mathrm{Si}_{3}$ and $\mathrm{Zn}_{2} \mathrm{Zr}_{3} \mathrm{Si}$ ) together with the main constituent $\mathrm{Zn}$. Mean-while the presence of $\mathrm{Zn}$ resulted from profusion of zinc within the bath formulation, whereas there is absence of elemental $\mathrm{Al}$ and $\mathrm{Si}$ as single phase. This implied that the bath composition was homogeneous. The three intermetallic phases contributed to the enhanced coating performance observed considering that they behave as true compound instead of individual materials. The most significant intermetallic of interest is $\mathrm{Zn}_{2} \mathrm{Zr}_{3} \mathrm{Si}$ and it must be appreciated that it occurred over range on the diffractogram. It is suspected to contribute tremendously to the significant structural and adhesion properties as earlier observed from SEM/EDS.

Thermo-mechanical analysis: The thermo-mechanical data for the coatings with and without zirconia is as shown in Fig. 6. The thermo-mechanical hardness increases as the zirconia composition increased, for example, composite coating with $5 \% \mathrm{ZrO}_{2}$ have $185 \mathrm{HNV}$ hardness compared with $250 \mathrm{HNV}$ for $15 \% \mathrm{ZrO}_{2}$ coating. The zirconia composition increases in a non-linear correlation with the hardness, which implies that the electroplating bath reactions are diffusion controlled [29]. This is in agreement with earlier report that showed that the coating efficiencies, micro-hardness and wear behaviour increased with addition of zirconia [21]. This study adduced

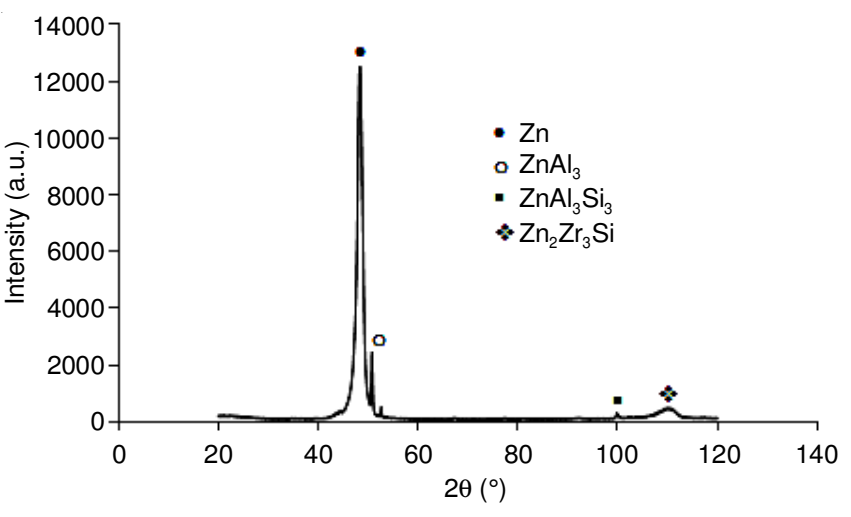

Fig. 5. XRD of $\mathrm{Zn}-15 \mathrm{Al}_{6} \mathrm{O}_{13} \mathrm{Si}_{2}-15 \mathrm{ZrO}_{3}$ composite coating

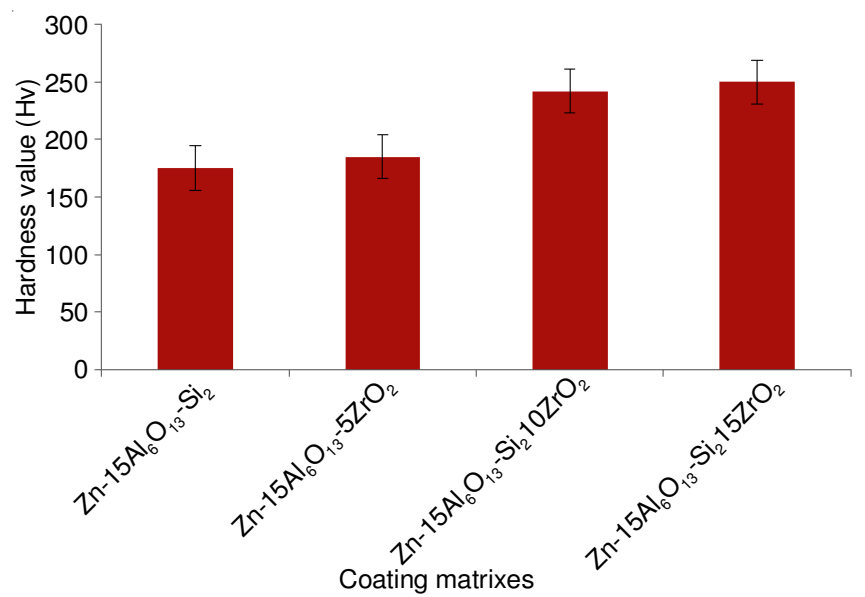

Fig. 6. Thermo-mechanical hardness trends of $\mathrm{Zn}-15 \mathrm{Al}_{6} \mathrm{O}_{13} \mathrm{Si}_{2}$ and $\mathrm{Zn}$ $15 \mathrm{Al}_{6} \mathrm{O}_{13} \mathrm{Si}_{2}-15 \mathrm{ZrO}_{3}$ deposits after heat-treatment

this trend to the fact that increasing $\mathrm{ZrO}_{2}$ concentration at stable tends to reduce zinc domination and it has also been documented that an increase in particulate concentration in bath formulation results to massive particulates deposition. It is established that ceramics composite particles evolve structural modification vis- $a$-vis the grain structure and have tremendous strengthening effect on mechanical behaviour [5,30]. Also it (a)

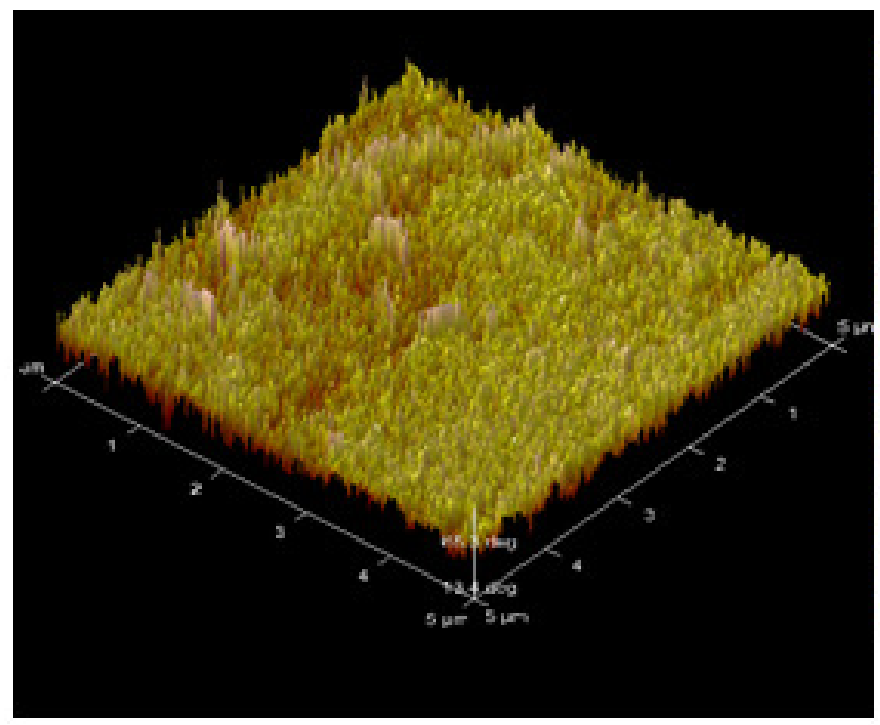

(b)

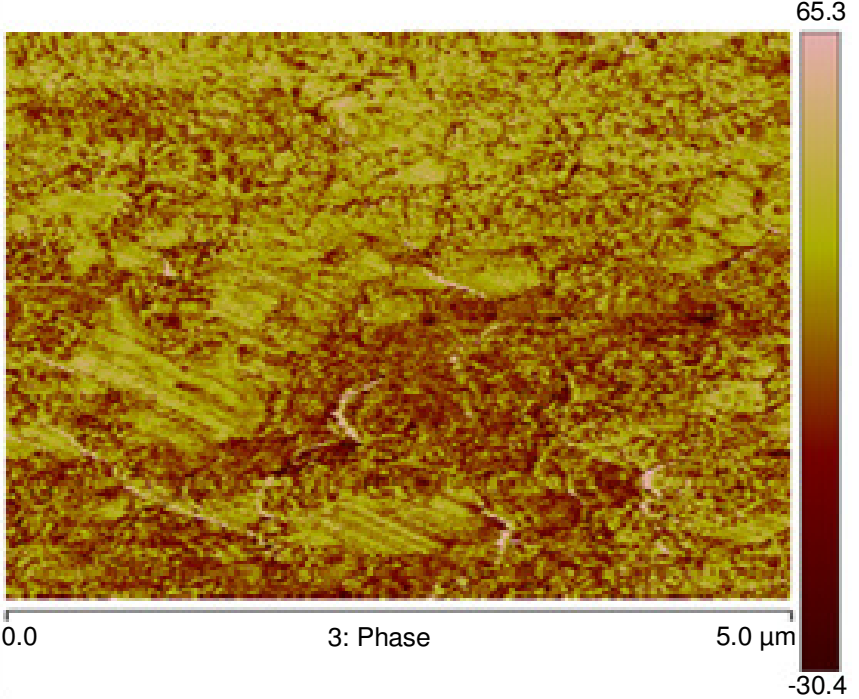

Fig. 4. AFM Microstructure of $\mathrm{Zn}-15 \mathrm{Al}_{6} \mathrm{O}_{13} \mathrm{Si}_{2}-15 \mathrm{ZrO}_{2}$ composite coating 

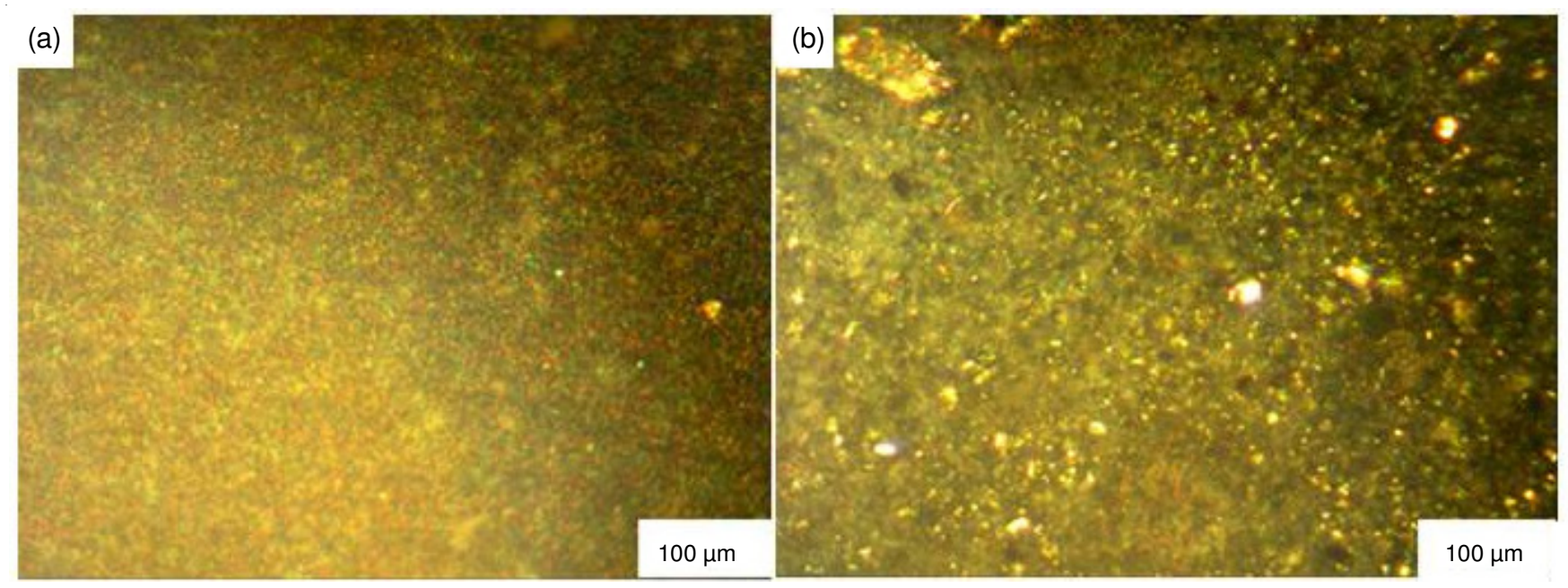

Fig. 7. Micrograph of $\mathrm{Zn}-15 \mathrm{Al}_{6} \mathrm{O}_{13} \mathrm{Si}_{2}$ and $\mathrm{Zn}-15 \mathrm{Al}_{6} \mathrm{O}_{13} \mathrm{Si}_{2}-15 \mathrm{ZrO}_{2}$ after heat-treatment

must be emphasized that this results is expected since the zirconia composite coatings does not behave as intermetallic but rather as true compound rather as shown from XRD data.

The micrographs of heat treated composite coatings with and without $\mathrm{ZrO}_{2}$ is shown in Fig. 7. There is virtually no defect with uniform and smooth surfaces for sample without $\mathrm{ZrO}_{2}$ while $\mathrm{ZrO}_{2}$ reinforced composite coating is characterized with whitish spots suspected to be induced coating and localized attack.

Electrochemical assessment: The combination of Fig. 8 and Table- 4 showed the potentiodynamic polarization data for the composite coatings with and without $\mathrm{ZrO}_{2}$ in $3.65 \% \mathrm{NaCl}$ solution. Theoretically, there is a relationship between the current density, polarization resistance and corrosion rate; for example, while both current density and corrosion rate increases, polarization resistance will decreased [1].

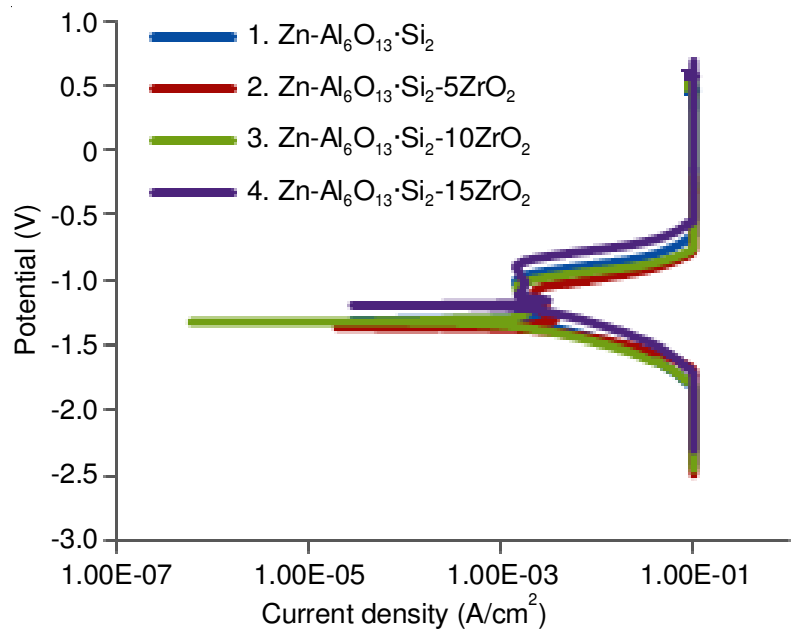

Fig. 8. Electrochemical linear polarization plots of deposited composite coatings

The corrosion rate and current density decreased tremendously as the nano-zirconia composition increases. The material wastage in form of corrosion rate decreased as the zirconia nanoparticles increases and there is non-linear relationship, which predicates that the system is diffusion reaction controlled. It is also suspected that zirconia introduction acted as

\begin{tabular}{|c|c|c|c|c|}
\hline \multicolumn{5}{|c|}{$\begin{array}{c}\text { TABLE-4 } \\
\text { SUMMARY OF THE POTENTIODYNAMIC } \\
\text { POLARIZATION RESULTS OF THE COMPOSITE } \\
\text { COATING WITH AND WITHOUT ZrO } \mathrm{Zr}_{2}\end{array}$} \\
\hline Sample matrixes & $\begin{array}{c}E_{\text {corr }}, \\
\text { Obs (V) }\end{array}$ & $\mathrm{i}_{\text {corr }}(\mathrm{A})$ & $\begin{array}{c}\mathrm{CR} \\
\text { (mm/year) }\end{array}$ & $\operatorname{PR}(\Omega)$ \\
\hline $\mathrm{Zn}-\mathrm{Al}_{6} \mathrm{O}_{13} \cdot \mathrm{Si}_{2}$ & -1.4204 & 0.001096 & 0.49006 & 5.181 \\
\hline $\mathrm{Zn}-\mathrm{Al}_{6} \mathrm{O}_{13} \cdot \mathrm{Si}_{2}-5 \mathrm{ZrO}_{2}$ & -1.1776 & 0.000532 & 0.35892 & 17.57 \\
\hline $\mathrm{Zn}-\mathrm{Al}_{6} \mathrm{O}_{13} \cdot \mathrm{Si}_{2}-10 \mathrm{ZrO}_{2}$ & -1.1761 & 0.000408 & 0.24757 & 44.49 \\
\hline $\mathrm{Zn}-\mathrm{Al}_{6} \mathrm{O}_{13} \cdot \mathrm{Si}_{2}-15 \mathrm{ZrO}_{2}$ & -1.2158 & 0.000401 & 0.18718 & 77.57 \\
\hline
\end{tabular}

not only nucleation sites and still as inoculant which improved the microstructure refinement. Apart from the fact that the types of phases, homogeneity of the crystals and size uniformity have considerable impacts on the coating performance, it plays tremendously role in the corrosion resistance. The least corrosion rate obtained is approximately $0.19 \mathrm{~mm} / \mathrm{yr}$, which occurred with $\mathrm{Zn}-\mathrm{Al}_{6} \mathrm{O}_{13} \cdot \mathrm{Si}_{2}-15 \mathrm{ZrO}_{2}$ while the composite without zirconia have corrosion rate of $0.49 \mathrm{~mm} / \mathrm{yr}$. The improvement can be attributed to the formation of favourable intermetallic phases in the alloy, which are suspected to behave like true compound. The presences of these phases are concluded to mitigate external forces and they act as dislocation motion barrier with attendant reduction in grain growth [31,32]. This is in line with SEM observations that reflect fine and uniform grain sizes, which confer surface strengthening effects on materials. In that, good morphology affects easy penetration of environmental solution within the coating. The polarization resistance $\left(R_{p}\right)$ follows contrary trend with composite coating without zirconia having the lowest value $(5.181 \Omega)$ and increasing progressively until reaching the highest value $(77.57 \Omega$ ) for $15 \% \mathrm{ZrO}_{2}$ reinforced composite. The thinking is that the addition of zirconia particles in the $\mathrm{Zn}-\mathrm{Al}$ matrix enhances the adhesion behaviour to resist the deterioration. The least corrosion potential is about $-1.42 \mathrm{mV}$ for nanocomposite without zirconia and $-1.22 \mathrm{mV}$ for $\mathrm{Zn}-\mathrm{Al}_{6} \mathrm{O}_{13} \cdot \mathrm{Si}_{2}-15 \mathrm{ZrO}_{2}$ composite.

The micrograph of composite coating with and without zirconia after corrosion test is shown in Fig. 9. The micrograph of $\mathrm{Zn}-\mathrm{Al}_{6} \mathrm{O}_{13}$. $\mathrm{Si}_{2}$ composite is characterized with whitish corrosion products, which are widely spread and uniformly distributed and present were scattered localized attacks (Fig. 9a). The $\mathrm{ZrO}_{2}$ reinforced composite (Fig. 9b) have virtually 

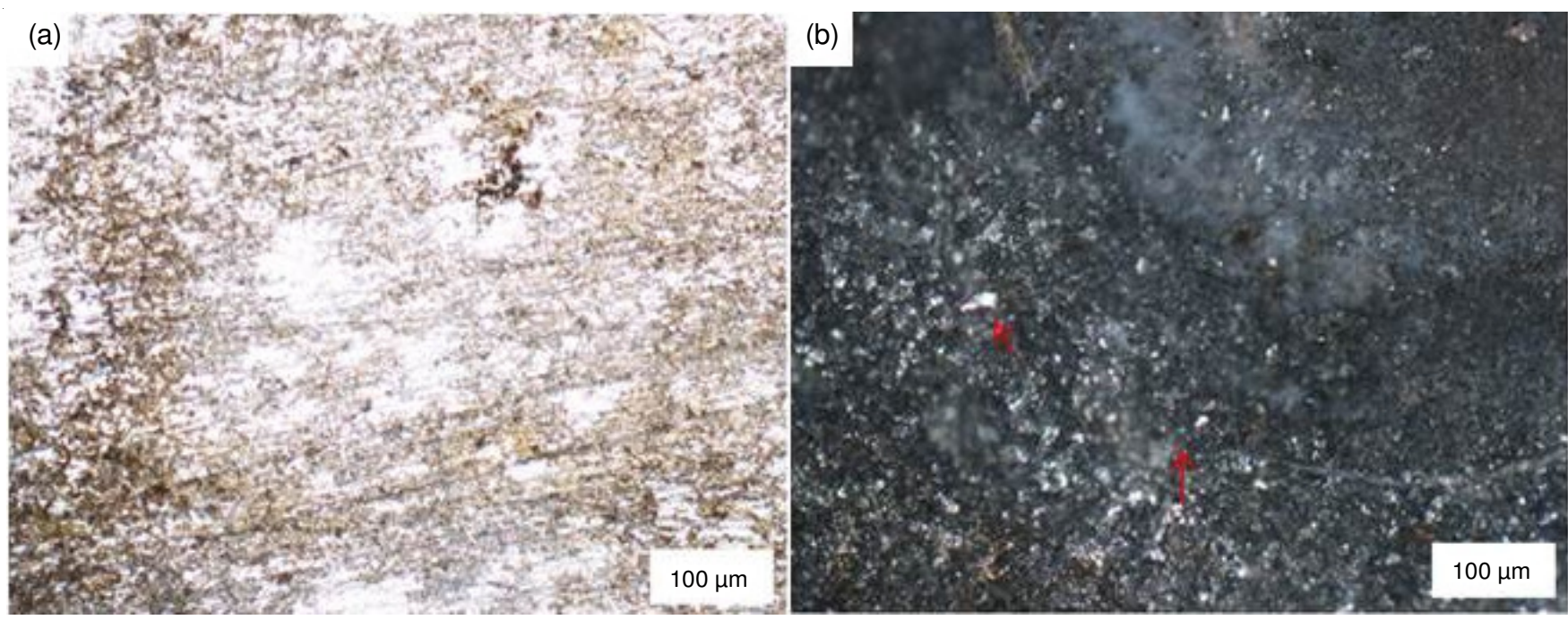

Fig. 9. Micrograph of $\mathrm{Zn}-15 \mathrm{Al}_{6} \mathrm{O}_{13} \mathrm{Si}_{2}$ and $\mathrm{Zn}-15 \mathrm{Al}_{6} \mathrm{O}_{13} \mathrm{Si}_{2}-15 \mathrm{ZrO} \mathrm{O}_{2}$ after corrosion test

no corrosion products with few whitish grains considered to be coating remnant and pronounced localized attacks.

\section{Conclusions}

The following conclusions can be drawn from this work, which are in relation to thermal stability and electrochemical behaviour of quaternary zirconia reinforced $\mathrm{Zn}-\mathrm{Al}_{6} \mathrm{O}_{13} \cdot \mathrm{Si}_{2}$ composite in chloride solution on mild steel:

- $\mathrm{ZrO}_{2}$ reinforced alumina silica composites were successfully fabricated by electrolytic deposition technique.

- The surface morphology and topography studies revealed that the composite particles have strong strengthening effects due to formation of excellent uniform grain structure and growth.

- The thermal stability and corrosion properties were tremendously improved due to the presence of intermetallic phases; $\mathrm{ZnAl}_{3}, \mathrm{ZnAl}_{3} \mathrm{Si}_{3}$ and $\mathrm{Zn}_{2} \mathrm{Zr}_{3} \mathrm{Si}$ and they were noted to behave as true compound.

- Increasing the $\mathrm{ZrO}_{2}$ content in the composite provide better thermo-mechanical and electrochemical properties.

\section{ACKNOWLEDGEMENTS}

This study is based upon work supported financially by the National Research Foundation. The authors acknowledge the support from Surface Engineering Research Centre (SERC), Tshwane University of Technology, Pretoria, South Africa.

\section{REFERENCES}

1. O.S.I. Fayomi and A.P.I. Popoola, Surg. Eng. Appl. Electrochem., 51, 76 (2015);

https://doi.org/10.3103/S1068375515010068

2. S.K. Tiwari, R.K. Sahu, A.K. Pramanick and R. Singh, J. Surf. Coat. Technol., 205, 4960 (2011);

https://doi.org/10.1016/i.surfcoat.2011.04.087.

3. A.P.I. Popoola, O.S.I. Fayomi and O.M. Popoola, Int. J. Electrochem. Sci., 7, 4898 (2012).

4. A.P.I. Popoola, O.S.I. Fayomi and O.M. Popoola, Int. J. Electrochem. Sci., 7, 4860 (2012)

5. O.S.I. Fayomi and A.P.I. Popoola, Int. J. Electrochem. Sci., 7, 6555 (2012).

6. M. Lekka, N. Kouloumbi, M. Gajo and P.L. Bonora, Electrochim. Acta, 50, 4551 (2005); https://doi.org/10.1016/j.electacta.2004.11.067.
7. C.N. Panagopoulos, E.P. Georgiou, M.G. Tsoutsouva and M. Krompa, J. Coat. Technol. Res., 8, 125 (2011); https://doi.org/10.1007/s11998-010-9278-x.

8. L.M. Chang, D. Chen, J.H. Liu and R.J. Zhang, J. Alloys Comp., 479, 489 (2009); https://doi.org/10.1016/j.jallcom.2008.12.108.

9. M.G. Ger and R. Grebe, Mater. Chem. Phys., 87, 67 (2004); https://doi.org/10.1016/j.matchemphys.2004.04.022.

10. P.A. Gay, P. Bercot and J. Pagetti, Surf. Coat. Technol., 140, 147 (2001); https://doi.org/10.1016/S0257-8972(01)01043-X.

11. A. Mazahery and M.O. Shabani, J. Mater. Eng. Perform., 21, 253 (2012); https://doi.org/10.1007/s11665-011-9867-6.

12. O.S.I. Fayomi, A.P.I. Popoola and V.S. Aigbodion, J. Alloys Comp., 623, 328 (2015); https://doi.org/10.1016/j.jallcom.2014.10.013.

13. O.S.I. Fayomi, A.P.I. Popoola and V.S. Aigbodion, J. Alloys Comp., 617, 455 (2014); https://doi.org/10.1016/j.jallcom.2014.07.141

14. O.S.I. Fayomi, M. Abdulwahab and A.P.I. Popoola, J. Ovonic Res., 9 , 123 (2013)

15. G. Yang, S. Chai, X. Xiong, S. Zhang, L. Yu and P. Zhang, Transc. Non-Ferrous Metals Soc. China, 22, 366 (2012); https://doi.org/10.1016/S1003-6326(11)61185-0.

16. O. Sancakoglu, O. Culha, M. Toparli, B. Agaday and E. Celik, J. Mater. Des., 32, 4054 (2011); https://doi.org/10.1016/j.matdes.2011.03.027.

17. H.R. Safaei, M.R. Safaei and V. Rahmanian, Open Electrochem. J., 4, 1 (2012); https://doi.org/10.2174/1876505X01204010001

18. A.M. Pillai, A. Rajendra and A.K. Sharma, J. Coat. Technol. Res., 9, 785 (2012); https://doi.org/10.1007/s11998-012-9411-0.

19. M.K. Punith Kumar and T.V. Venkatesha, J. Chem. Pharm. Res., 5, 253 (2013).

20. O.S.I. Fayomi and A.P.I. Popoola, J. Alloys Comp., 637, 382 (2015); https://doi.org/10.1016/j.jallcom.2015.02.154.

21. O.S.I. Fayomi, A.P.I. Popoola and A.O. Inegbenebor, Results in Physics, 4, 79 (2014); https://doi.org/10.1016/j.rinp.2014.05.001.

22. B.M. Praveen and T.V. Venkatesha, Appl. Surf. Sci., 254, 2418 (2008); https://doi.org/10.1016/j.apsusc.2007.09.047.

23. A.P.I. Popoola, S.L. Pityana and O.M. Popoola, Int. J. Electrochem. Sci., 6, 5038 (2011).

24. A. Gomes, T. Frade and I.D. Nogueira, Curr. Microsc. Contrib. Adv. Sci. Technol., 2, 1146 (2012).

25. W. Zhang, W. Liu and C. Wang, J. Eur. Ceram. Soc., 22, 2869 (2002); https://doi.org/10.1016/S0955-2219(02)00063-8.

26. H.Y. Zheng, M. An and J. Lu, J. Appl. Surf. Sci., 254, 1644 (2008); https://doi.org/10.1016/j.apsusc.2007.07.110. 
27. B. Subramanian, S. Mohan and S. Jayakrishnan, Surf. Coat. Technol., 201, 1145 (2006); https://doi.org/10.1016/j.surfcoat.2006.01.042.

28. G.A. Finazzi, E.M. de Oliveira and I.A. Carlos, Surf. Coat. Technol., 187, 377 (2004); https://doi.org/10.1016/j.surfcoat.2004.01.029.

29. S.A. Williams and P.L. Chow, J. Math. Anal. Appl., 62, 157 (1978); https://doi.org/10.1016/0022-247X(78)90227-5.
30. M.S. Vasilyeva, V.S. Rudnev, I.A. Korotenko and P.M. Nedozorov, Prot. Met. Phys. Chem. Surf., 48, 106 (2012); https://doi.org/10.1134/S2070205111050224.

31. K. Vathsala and T.V. Venkatesha, Appl. Surf. Sci., 257, 8929 (2011); https://doi.org/10.1016/j.apsusc.2011.05.067.

32. O.L. Hammami, L. Dhouibi, P. Bercot, E.M. Rezrazi and E. Triki, Int J. Corros., Article ID 301392 (2012); https://doi.org/10.1155/2012/301392. 